\title{
AFFECTIVITY AND INTIMACY IN DORIS LESSING'S LOVE, AGAIN AND ROSA MONTERO'S LA CARNE
}

\author{
CARMen García NAVARro \\ Universidad de Almería
}

\begin{abstract}
This article discusses the literary similarities between Doris Lessing's Love, Again (1995) and Rosa Montero's La carne (2016), emphasising the parallels between these writers' interest in women's ageing experiences and the role that the main characters in both of these novels play in the contemporary cultural scene. Of particular interest for this analysis is the experience of these two female authors, whose novels were written in historical periods that are marked by major social and economic upheavals, between the 1990s and the first two decades of the twenty-first century. I suggest that their respective productions problematise the notions of affectivity and intimacy and, notably, showcase the contributions made by women, as creative agents of social and cultural change, in the understanding of the process of ageing in contemporary Europe.
\end{abstract}

KEY WORDS: Doris Lessing, Rosa Montero, women's ageing, affectivity, intimacy.

\section{Afectividad e intimidad en Love, Again de Doris Lessing y La carne de Rosa Montero}

Este artículo estudia las similitudes literarias entre las novelas Love, Again de Doris Lessing (1995) y La carne (2016) de Rosa Montero, destacando el interés paralelo de las dos escritoras en las experiencias de envejecimiento de las mujeres, junto con el papel de sus protagonistas en la escena cultural contemporánea. Interesa de manera especial conocer la experiencia de estas novelistas, cuyos textos se han producido en períodos históricos convulsos desde el punto de vista social y económico, en concreto entre los años noventa del siglo XX y las dos primeras décadas del XXI. Sugiero que las producciones de ambas autoras problematizan nociones sobre la afectividad y la intimidad, y destaco las aportaciones de las mujeres, como agentes creadoras de cambios sociales y culturales, respecto a los procesos de envejecimiento en el contexto europeo contemporáneo.

PALABRAS ClAVE: Doris Lessing, Rosa Montero, envejecimiento de las mujeres, afectividad, intimidad.

Choose a younger bed

For I cannot bear

To live with you when I am the older one. -Anne Carson, Si no, el invierno. Fragmentos de Safo (2019)

García Navarro, Carmen (2021), "Affectivity and Intimacy in Doris Lessing's Love, Again and Rosa Montero's La carne", Lectora, 27: 227-242. ISSN: 1136-5781 D.O.I.: 10.1344/Lectora2021.27.11, mgn024@ual.es

Recepció: 13 de desembre de 2020 - Acceptació: 23 d'abril de 2021 
Rosa Montero met Doris Lessing in London in 1997, when she interviewed Lessing for the cultural supplement of the newspaper El País, "El País Semanal". ${ }^{1}$ Lessing was then seventy-eight years old and had just published the second volume of her autobiography, Walking in the Shade. Volume Two of My Autobiography, 1949$1962 .{ }^{2}$ In her interview, Montero asked Lessing about her experience of ageing, to which Lessing responded: "Lo que está usted preguntando es cómo llevo ser vieja, ¿no? [...] No hay más remedio que vivir la vejez. No puedes hacer nada contra ella" (Lessing qtd. in Montero, 2013: n.p.). ${ }^{3}$ Montero returned to the topic by choosing a different approach:

- [...] para mí usted es una especie de exploradora. Por favor, dígame que también a esa edad hay momentos en los que la vida resulta hermosa. -Yo nunca pensé que la vida fuera hermosa.

- Pues entonces dígame por lo menos que todavía se conserva la curiosidad, y la excitación de conocer cosas nuevas, y el placer de escribir...

-Sí, eso sí. Todo eso se mantiene aún intacto. (Lessing qtd. in Montero, 2013: n.p. $)^{4}$

The exchange above shows Montero's admiration for Lessing, which ran parallel to her desire to prompt an answer to a question that portrayed old age as an enigma, a period that only allows for glimpses "en los que la vida resulta hermosa". Lessing's answer dispelled any hint of idealisation about this stage of life and focused on two main ideas: the inevitability of old age throughout the course of life and the importance of keeping curiosity alive, of rekindling the desire to continue writing, an activity in which Lessing had engaged since her youth. The interview does not contain any allusions to the then-newly formed British Parliament with a Labour majority, which held the record of having 120 female

\footnotetext{
${ }^{1}$ For this article I refer to the digital edition of the interview (2013).

2 The first part, entitled Under My Skin. Volume One of My Autobiography, to 1949, had been published in 1994. Both volumes were reissued in 1995 and 1998 respectively and were translated into different languages, including Spanish, the first one by Marta Pessarrodona and the second by María Faidella.

3 "What you are asking is how I am doing getting old, are you? [...] You have to live old age. You can't do anything against it" (translations in this and subsequent footnotes are mine).

4 “- $[. .$.$] to me you are a kind of explorer. Please tell me that, at that age, there are also times when$ life is beautiful.

-I never thought life was beautiful.

-Well then, at least tell me that one is still curious, excited to learn new things, and can take pleasure in writing...

-Yes, that's true. All of that remains intact".
} 
MPs, nor is there any mention of the terrorist scourge in Spain, still active at the time, which also coincided with the first conservative government after fifteen years of socialist rule by Felipe González, who had become president in October 1982. This seems remarkable, given Lessing's interest in calibrating political trends and in questioning the frameworks of representation of both individual and collective experience, not only in her narrative and theatre production, but also in her articles and interviews (García Navarro, 2019). ${ }^{5}$ Moreover, pain is clearly evident in the interview with Montero: Lessing's mother's pain; the pain felt by Lessing about the difficult relationship with her mother; and people's suffering, inherent to and part of life, caused by, among other things, the uncertainty and fear of approaching old age. The aforementioned are major subject matters in Lessing's writing throughout her career. Two years before the interview, in 1995, Lessing had published Love, Again, in which the social consideration of old age is a central theme. ${ }^{6}$ In this article, Lessing's text is placed in a dialogic relationship with some of Montero's texts where ageing and elderly women working in cultural and creative environments have a significant presence, including La carne (2016), ${ }^{7}$ a novel that is relevant to the aim of this paper due to its main narrative knot and the depth of its approach regarding the topic under study here.

In what follows, I will discuss the intersection of perspectives and focuses that can be identified in Lessing's Love, Again and in Montero's La carne, with a view to gaining a better understanding of the confluence of gender and ageing in contemporary culture. The context is a Europe crisscrossed by challenges such as the progressive erosion of the welfare state from the 1990s onwards, the aftermath of the 2008 economic crisis, and the initial salvos of Brexit, at a time when new forms of relationship seem to be developing between the European states and, in turn, between Europe and the rest of the world. I will take these writings as part of the ethical basis underlying both writers' interests, without seeking to draw any firm conclusions. My intention is to contribute to the discussion on the visibility of women who are in the process of ageing in contemporary European writings. I suggest that the notions of affectivity and intimacy, as well as representations of commitment and transgression, are pivotal elements in the articulation of a discourse on female ageing in Love, again and in La carne. Even though Lessing and Montero belong to different generations, they arguably use female ageing

\footnotetext{
${ }^{5}$ Elsewhere I have spoken about the fact that Lessing's political activity, to which she had devoted time and energy from a very young age, together with commitments of both intimate and familial nature, took time away from the practice of her early vocation as a writer.

${ }^{6}$ Published in Spain in 1996 and also translated by Pessarrodona. For this article I use the English edition from 1997. See García Navarro (2019).

${ }^{7}$ For this article I use the 2017 edition.
} 
processes in the same way, as a mural painting where discourses about the body, affect, intimacy and desire are constructed and reconstructed, both works sharing their awareness of the latter stages of the course of life (Worth and Hardill, 2015). Similarly, both writers resort to older women as protagonists who resist selfcomplacency and hopelessness (Segal, 2014: 221).

\section{Approaches: A World Made of Leather ${ }^{8}$}

The approach used for the joint discussion of these two works is based on the notion of the Reifungsroman, a term coined by Barbara Frey Waxman following May Sarton (qtd. in Waxman 1990: 2). These narratives tend to focus on age, gender and social class as factors that converge in a social scenario that depicts both old women and ageing processes as products solely or mainly defined by culture (Gullette, 2004: 11). In this scenario, Lessing and Montero showcase women undergoing ageing processes and examine them in particular in relation to the cultural, social, and work spheres, as subjects who question what they feel and what they see, and who in turn reevaluate their behaviour and beliefs. From a gender perspective, the discourse of transgression espoused by both their characters can be examined by relying on the marks of differentiation between and suppression of the private and the public spheres. There has been recurring academic interest in commitment and transgression as seen in some of the female characters undergoing ageing processes in Lessing's work, including works by Perrakis (1999), Rubenstein (1994, 2001), Sprague (1994), and Watkins (2015), among others. A similar interest can be identified in some of Montero's ageing female characters, such as the ones presented in this article. Commitment here refers to a desire to disengage oneself from obedient attitudes regarding norms and social pacts that can be perceived as obsolete or simply conventional.

Lessing and her writings have been the subject of academic discussions concerning the transcultural and transnational scope of her work in the literature of the twentieth and early twenty-first centuries, studied from different angles and methodological approaches. ${ }^{9}$ For some authors, Lessing is a guide in this area, as Montero told Lessing in the interview referred to earlier. Similarly, Lara Feigel considers Lessing to be a model, as a woman and as a writer, an inspiration for personal and authorial searches, as seen in Feigel's Free Woman. Life, Liberation and Doris Lessing (2018), a book at the crossroads between autobiographical

\footnotetext{
${ }^{8}$ For the title of this section, I have adapted part of the title of a poem by Juana Castro, entitled "Toda la piel del mundo" $(2009,2010)$, which could be translated as "All the leather in the world".

${ }^{9}$ Lessing's recent centenary led to a multiplicity of meetings and exchanges regarding her work. See $<$ https://www.uea.ac.uk/library/british-archive-for-contemporary-writing/a-z-writers/dorislessing>, and García Navarro (2019).
}

230

Lectora, 27 (2021): 227-242. ISSN: 1136-5781 D.O.I.: 10.1344/Lectora2021.27.11 
narration and specialised criticism. Lessing's narrative works have also been compared to those of other writers. As stated by Detlev Gohrbandt, when problematising the comparison between writers, it makes sense to enquire about thematic, stylistic, and other aspects, articulated around a specific common geospatial or historical context (1998: 129). This has been the case with comparative studies such as those focused on Lessing and Dorothy Richardson (Kaplan, 1974), Lessing and Virginia Woolf (Rubenstein, 1994; Scott, 1997; Sprague, 1994), Lessing and Bessie Head (Gohrbandt, 1998), and Lessing and Pearl S. Buck (Liang and Yao, 2010).

In view of the above, and bearing in mind Montero's interest in Lessing and her work, after reading La carne I wondered whether both writers' novels shared approaches in their treatment of ageing, memory, and expressions of affect and intimacy. I also thought it interesting to investigate whether the literary approaches in both Lessing's and Montero's texts could be regarded as belonging to a genealogy of writers committed to the representation of ageing processes in women who acknowledge their vulnerability while at the same time they advocate for a unique personal life project that integrates psycho-emotional, economic and cultural aspects. To achieve my purpose, it was necessary first to detect Lessing's influence on or trace in other contemporary authors writing in either Spanish or the other languages of Spain, which, in my view, had its ultimate expression in $\mathrm{La}$ carne by Montero. Indeed, Lessing is mentioned in a poem by Juana Castro entitled "Toda la piel del mundo", included in the volume Heredad, seguido de Cartas de enero (2010). ${ }^{10}$ All the leather in the world is the metaphor for a bag, "son cosa de mujeres, tonterías /lo llevan para meter el pintalabios, /el móvil, quizás una compresa. Y te olvidas. / Pero ellas no olvidan...” (Castro, 2010: 275). The world that is contained in a handbag includes items related to the physiological functions of women of childbearing age ("una compresa"), along with other items that evidence the passage of historical time. The lyrical voice

\footnotetext{
${ }^{10}$ First published in Vulva dorada y lotos (2009: 85-86). Castro made a statement of intent in this regard in another poem, "Anunciación" ("Annunciation"), in which the poetic persona, faced with the evidence of old age, chooses self-affirmation: "Pues sí, he decidido que soy vieja / y he decidido además que voy a proclamarlo, / porque así no habrá malentendidos” (2010: 275). Castro was awarded the Spanish "Premio de la Crítica" for Heredad, seguido de Cartas de enero in 2011. The allusion to the blessings of age connects with Betty Friedan's Fountain of Age (2006). These blessings are also present in Alicia Ostriker's poem "The Blessing of the Old Woman, the Tulip, and the Dog” (2009). In each of the three stanzas, the lyrical voice changes: an old woman, a dark red tulip, and subsequently a dog define what it is to feel blessed. The stanza related to ageing includes three essential factors in people's lives: work, eroticism, and spirituality, all of which permeate the trace of one's life experience over time: "To be blessed / said the old woman / is to live and work / so hard / God's love / washes right through you / like milk through a cow" (Ostriker, 2014: 3).
} 
prides itself in welcoming goods that bear witness to the advances achieved by women throughout history, such as the freedom to read any book; thus, in this self-contained world of the bag, we find "[a]l fondo la novela, la última, de Doris Lessing" (Castro, 2010: 275). Without specifying which novel, the allusion to Lessing shifts the gaze towards a flagship author of the period, considered as "a chronicler of our time" (Greene, 1994: 13), and offers clues about the cultural and spatio-temporal context in which Castro is writing. Lessing and her work are, therefore, an axis and nexus for contemporaneous female authors and readers. They rely on these signs to build parts of their identities through the experience of reading, with its effects on the perception of the world (Bruner, 2004; Larrosa, 1996), as an activity increasingly enjoyed by women since the Enlightenment (Wittmann 2004). For her part, Maria Àngels Francés Díez sees Lessing's influence in both theme and thought in L'hora violeta by Montserrat Roig (Escandell, 2011: 270). Roig mentions Lessing's observations in the 1971 foreword to The Golden Notebook (1962) about the fears shared by many women, one of them being the fear that men will hear what afflicts and worries women who live in the same historical time (Roig, 1985: 30). Furthermore, Alicia Redondo Goicoechea qualifies The Golden Notebook as one of "los espacios más bellos del feminismo" (2009: 8), ${ }^{11}$ while Sara Mesa states that the novel could be disconcerting (2018: n.p.), because of the shift in Lessing's feminism towards more ambiguous positions over the years. In addition, it should not be forgotten that, after the publication of The Golden Notebook, Lessing had witnessed the conflicting opinions prompted by its publication, which drove her to write in the 1971 foreword that "the essence of the book [...] says implicitly and explicitly, that we must not divide things off, must not compartmentalize" (1994: 10).

Returning to Montero, her agency as an author has been recognised as a result of both her profession as a journalist and her work as a novelist, which is evident in her numerous published works and the reception by the public and critics, as well as by the abundance of studies on her narratives (Redondo Goicoechea, 2009). ${ }^{12}$ Some contributions include insights into the amorous discourse portrayed by female characters in La función Delta and Te trataré como a una reina (Moszczyńska-Dürst and Pardo Fernández, 2013), together with those that investigate Montero's fiction about the recent economic crisis in Spain and neighbouring countries (Bezhanova, 2020). Specifically, La carne has been compared to Mi sa che fuori é primavera (2015) by the Italian author Concita de Gregorio (Russo, 2017). Lucia Russo studies the power of writing as a therapeutic

\footnotetext{
11 "One of the most beautiful spaces of feminism".

${ }^{12}$ Most of the references to Montero's work can be found on the writer's website, in addition to those provided in this article: www.rosamontero.es.
}

232

Lectora, 27 (2021): 227-242. ISSN: 1136-5781 D.O.I.: 10.1344/Lectora2021.27.11 
activity in grieving processes, whether in the face of workplace conflicts or the loss of love, present in La función Delta, Bella y Oscura, and La hija del caníbal (2017: 79). Of interest here is also the essentially liberating potential of art for the hero of La carne, sixty-year-old Soledad, for whom art and aesthetic experience provide the opportunity to live different lives from within one's own, having an effect that is "lenitivo contra la oscuridad" (Montero, 2017: 188). ${ }^{13}$ Another sixty-year-old woman, Lucía, the protagonist of La función Delta, reflects on ageing and illness (be they related to each other or not) in a fictionalised diary, and reveals her fear of pain and the obscurity of her mood (Montero, 1981: 33, 231) as intrinsic to the precarity of life (79). However, until the person becomes fully aware of the support and liberation that art (not only writing, but any kind of artistic representation) can bring, the personal experience of darkness caused by the passage of time and the emptiness felt by the absence of love causes stupor and anguish, as is the case with Soledad, the protagonist of La carne, and Sarah, the protagonist of Love, Again.

\section{Themes}

In Love, Again and in La carne the presence of women undergoing ageing processes reflects the interest of both writers in exploring how old age is considered socially in Europe in the late twentieth and the early twenty-first centuries. Both novels provide a very accurate perception of contemporary society and contribute to locating and understanding the elderly or people in ageing processes (Hepworth, 2000). As mentioned above, similarities can be found in both novels concerning different aspects of transgression and commitment in disparate areas and the portrayal of the role of culture, specifically of the performing and visual arts, as key elements in the formation of identities throughout the course of life, particularly in the ageing stage. The protagonists conduct themselves and participate in society in a way that is determined not only by their personal history and the role of the affective dimension in their lives, but also by their degree of involvement in and commitment to their environment. This is the case of Sarah, aged sixty-five, director of an independent theatre company in London called The Green Bird, and of Soledad, about to turn sixty, an exhibition curator at a museum in Madrid. For both elderly women, their involvement in creative practices is a continuous process, not only because artistic practices are their modes of living, but because said practices allow these women to be in a continuous "rhizomic flow of affects" (Deleuze and Guattari qtd. in Fox, 2013: 531) that prompt the capacities to experiment and desire. Both novels were written between 1995 and 2016, when Lessing was 76 and Montero 65. At those moments,

13 "A balm against darkness". 
the two writers were actively involved in their writing careers. Their work was being produced, in the case of Lessing, in a Europe that had welcomed the fall of the Berlin Wall in November 1989 and where the incipient onslaughts of neoliberalism would be questioned by cultural practices, all relevant in Love, Again. As regards La carne, it deals with the migration flows to Spain as a host country for European and non-European citizens. Despite the 2008 economic crisis and its aftermath in terms of a circumstantial interruption of said migration flows, in 2016, the year of La carne's publication, the presence of diversity and multiculturality in Spain is still palpable. ${ }^{14}$ In my view, the relevance of these texts lies in their ability to convey a notion of Europe in permanent crisis, which occurs in parallel to an attempt to showcase the need to make visible new forms of coexistence in a society with a progressively ageing population. At the same time, both novels place their focus on subjects related to multiculturalism and thus highlight the creative opportunities of intercultural coexistence for the social, economic and cultural progress of the community. ${ }^{15}$ These frameworks also create opportunities to question what the protagonists were, what they are now, and what they want to be for the rest of their lives, while at the same time they can decide and act for themselves.

In general, age and the ageing body are perceived as barriers for women in the two stories, which offer reasonably reliable versions of ageing women who experience remarkably complex situations, not only because of the individual circumstances of their life journeys, but due to the social implications of their being members of a particular age group and gender. Both novels revolve around the world of work, affectivity, the body, intimacy, and the nature of love for Sarah and Soledad, who are both healthy and wealthy. Whether or not love is a common theme in Lessing's work has been extensively discussed (García Navarro, 2003, 2019; Güell i Devesa, 2015; Gruia, 2016; Perrakis, 1999; Tiger, 2007; Watkins, 2015), but in Love, Again, love is the leitmotif used to construct the identities represented by characters who are transitioning to old age. Sarah has had an extensive career in the performing arts and is, at the same time, aroused and overwhelmed by her feelings for Bill, a younger man in her theatre company, and by how events unfold. After many years without love, Sarah finds herself blushing in the presence of this young man, even if quite inappropriately (Watkins, 2015:

\footnotetext{
${ }^{14}$ For further knowledge on this topic, see Bezhanova (2020).

${ }^{15}$ Regarding the upward trend in population ageing globally and of the European population in particular, some studies have stressed the need to map out a new way of thinking about old age in Europe that contributes to new approaches based on perspectives of age, gender, and the distribution of responsibility between States and individuals, as the former are faced with the challenges of this demographic phenomenon. See Ramos Toro (2017), Rogers, Sánchez-Querubín and Kil (2020).
}

234

Lectora, 27 (2021): 227-242. ISSN: 1136-5781 D.O.I.: 10.1344/Lectora2021.27.11 
153). Her resistance to being engulfed by this love is fuelled by her feeling segregated from the circle of younger men and women in the theatre company, a state that makes her "wretched" (Segal, 2014: 220). Sarah sees this group as living within a dimension that is outside of her reach (Lessing, 1997: 222) and cannot even think that

the fact of us all, to get old, or even to grow older, is one so cruel that while we spend every energy in trying to avert or postpone it, we in fact seldom allow the realisation to strike home sharp and cold: from being this - and she looked around at the young people- one becomes this, a husk without colour. (Lessing, 1997: 136; emphasis in the original)

Love and desire are also present in La carne, as featured in the relationship between Soledad and a man called Adam, a handsome thirty-two-year-old Russian immigrant who works as a gigolo (Montero, 2017: 10). Soledad's relationship with the male prostitute begins when Soledad finds out that Mario, her lover, has decided to leave her because he has found out that his wife is expecting a baby. Soledad plots revenge against Mario by going to the Teatro Real with Adam to see Tristan and Isolda, a plan that Soledad and Mario had for her sixtieth birthday, sixty years of age that are perceived as "redondos y pesados como una sentencia" (17). ${ }^{16}$ Soledad uses the internet to buy Adam's company, to dispel the pain of being abandoned and the fear of never loving again, perceived, for her, as a symbolic space "entre dos nostalgias: la de lo que aún no has vivido y la de lo que ya no vas a poder vivir" (9). ${ }^{17}$

\section{Mirrors}

Interestingly, the ageing processes of both women, as their stories unfold, are not associated with the end of their reproductive life. However, it is true that the body retains the signs of the passage of time. Differences are made apparent by the body and with the body, and the value of those differences are also stored there. In her interview, Montero observed that Lessing did not seem to be bothered by the physical constraints of age and insisted on sitting on the floor as if that was no effort for her. But she found it difficult, even though she was still quite agile; leaning on her knee Lessing grunts: "Esto es la vejez, ¿se da cuenta? La vejez es esta dificultad para levantarse" (Lessing qtd. in Montero, 2013: n.p.). ${ }^{18}$ For Soledad and

\footnotetext{
16 "Round and heavy as a sentence".

17 "Between two nostalgias: for what you have not yet lived and for what you will no longer be able to live".

18 "This is old age, do you see? Old age is the difficulty of getting up".
} 
Sarah, the mirror reminds them of what they look like now. Soledad does not spare herself criticism at what she sees when she turns on her bedroom's light: she sees "todas tus carnes [...] desplomarse de repente como sometidas a una fuerza de gravedad 3G, mostrando ondas, hoyos, arrugas, desfallecimientos musculares. Se escrutó despacio en el espejo, sin compasión" (Montero, 2017: 25). ${ }^{19}$ Soledad struggles with herself, at times unable to accept what she sees, furious with her "negative construction of the ageing physical body" (Thorpe et al., 2015: 161). Her perceptions are turned into a soliloquy that combines the second and third person singular, firing assertions about herself ("todas tus carnes") and others that move her away from the reality in front of her: "el deterioro se agazapaba [...] de manera insidiosa y a menudo el interesado era el último en enterarse, como los cornudos del teatro clásico" (Montero, 2017: 25) ${ }^{20}$ For her part, Sarah contemplates in the mirror a good-looking woman "who had about her a dewy look far from the competent asperities appropriate to her real age" (Lessing, 1997: 141). This is due to the emotional movement produced by desire, "the elixirs romping in her blood" (141), mixed with a feeling of bitterness and emptiness, "as if life itself was being withheld from her" (159). Soledad and Sarah's efforts to recognise themselves is important because this self-recognition helps them own up to their present experience. Acceptance as the counterpart for considering that their bodies do not fit the idea of younger sexual ideals (Segal, 2014: 217) is therefore necessary for facing their anguish, in addition to their astonishment at their feelings, including the difficulty of accepting the loss of love and physical prime.

Curiously, when Sarah and Soledad invoke love, there is a double representation: the desire to fulfil that love, and its absence. Both Soledad and Sarah have known good times, and they need to distance themselves from them and gauge their current experience, which they both surrender to and resist at the same time. Sarah reflects on her role as depositary of a nostalgia that is impossible to dispel (Bazin, 2008). For her, the experience of being in love again is "painful" (Lessing, 1997: 180), because having to admit that this will probably be the last time she has the opportunity to intensely feel and experience being in love is unbearable for her. Soledad, after sharing both sexual intimacy and confidences with Adam, felt that she had "siete puñales en el corazón, en ese músculo primordial y supremo, doscientos sesenta gramos de carne y de necesidad de

\footnotetext{
19 "Your flesh [...] suddenly collapsing as if under the influence of 3G gravity, showing ripples, dimples, wrinkles, muscular weakness. She examined herself slowly in the mirror, without compassion".

20 "Deterioration lurked [...] insidiously and more often than not the person concerned was the last to know, like the cuckolds of classical theater".
} 
cariño" (Montero, 2017: 145). ${ }^{21}$ Soledad's experience with Adam places her at the centre "del deseo de amor" (72), ${ }^{22}$ without which life is "vacía, tediosa e insensata" (72). ${ }^{23}$ Beyond Soledad's visceral outburst at Mario's abandonment, her anger comes from a deeper psycho-emotional place that speaks of her need for proximity and commitment in her relationship with a man. But what Soledad knows about her relationship with Adam is one thing, and what she wants and fears at the same time is quite another; although Soledad wishes durability, she realizes that Adam's response to a tentative declaration will be unequivocal, as in the poem by Pilar Adón, "él dirá que su amor es de ahora" (2019: 52). ${ }^{24}$ The second reason leads to the territory of losses that originated from an individual and family past where there is an all-pervading hunger for love rooted in a wretched childhood. Unlike Sarah, who enjoyed a stable love life from a young age and then with her husband until his death twenty years before, Soledad has been deprived of love from very early on, which triggers her desire to "vivir aún lo que no había conseguido vivir en su juventud" (Montero, 2017: 42) ${ }^{25}$ In her relationship with Adam, Soledad is torn between that desire and the growing sense of a lack of freedom, due to her perception that a bond is being created with a single man. Something similar happens to Anna Wulf in The Golden Notebook, for whom the enjoyment of her sexuality is not complete if it is not linked to an emotional relationship with a man. The above contrasts with Sarah's perplexity in the face of her current situation, since for her the fulfilment of love only entails pain "for the body, the heart, and - worse - the mind, which observes the person it (the mind) is supposed to be governing behaving in a foolish and even shameful way" (Lessing, 1997: 136). Age brings certain blessings if you know how to pay attention to and take care of them, as Ostriker writes, and as noted in Montero's La ridicula idea de no volver a verte, a partly autobiographical and partly narrative text about Marie Skłodowska-Curie, who combined her passion and dedication to science with the passion for her husband, Pierre. On a different note, Sarah decides to remain active in order to recover from her painful experience after having encountered love, again (Lessing, 1997: 326). Similarly, Soledad finds renewed hope not only when she is witness to her successful exhibition at the National Library in Madrid (Montero, 2017: 232), but also when she decides to actively support the migrant community, as she discovers more about Adam's life beyond him being a gigolo who is paid to supply

\footnotetext{
21 "Seven daggers to the heart, that primordial and supreme muscle, two hundred and sixty grams of flesh and need of love".

22 "Of the desire for love".

23 "Empty, tedious and unwise".

24 "He will say that his love belongs to the present moment".

25 "To still live what she had not been able to live in her youth".
} 
pleasure to mature women (Montero, 2017: 227). Her progressive social involvement and commitment is connected with her personal need to take action to reduce the distance that separates her from Adam in terms of their social and economic status, which, quite unexpectedly, brings her "un minuto de gracia con el que recordarse" (Montero, 2017: 227). ${ }^{26}$

\section{Conclusions}

This article has sought to contribute to the literature on the link between ageing, feminism, and gender, in particular as regards the visibility of women ageing, as a determining life experience throughout the different stages and transitions of their lives. In the postmodern society of Love, Again and La carne, identities are created through the fragments of people's lives, of their past and present, of links with their community and within a social structure which, despite being part of a democratic setting, does not always offer assurances through affectivity that can attenuate or sustain the individual in the face of pain and loss. Thus, the pieces of a person's life experience must be arranged by the individual, as if putting together a puzzle, in order to find meaning. A greater knowledge of non-normative forms of ageing as regards social connectedness and affectivity bonds helps to understand that there is no single way to age, since values, norms and formerly valid social pacts are no longer absolute. All this encourages the presence and visibility of women undergoing ageing processes with unique life trajectories, in successful positions in public life, in diverse spaces such as social networks, who negotiate their identities on the move through interpersonal processes that are entangled with their own lifestyles.

Old age is a running theme in Love, Again, an "anticipated interior journey" (Tiger, 2007: 27) faced by Sarah. Something similar happens in La carne, a text which, like Lessing's, views female ageing from a perspective of deprivation and subsequent acceptance, giving way to the weaknesses and strengths of the protagonist. Quite interestingly, in La carne newly formed relationships - as that of the protagonist with the Russian man-, bodily appearance (as with Sarah in Love, Again) and, more importantly, the right to enjoy an active sex life (be it with a long-term partner or with a male prostitute) are revelatory. As is the case in Love, Again, Montero's novel also showcases the realms of work and the arts as fundamental elements that can contribute to giving meaning to the lives of women. La carne also includes the issue of immigration as part of the Spanish society of the twenty-first century. Although the main characters of the two novels are not disconnected from their environment, the feeling of distance and separation from others is bridged thanks not only to their involvement in their

26 "A minute of grace to recollect herself". 
areas of expertise, but also to their authority, which comes from being true agents that own up to the events that they remember, recreate and experience. Both Sarah's and Soledad's transitional experiences share an inner struggle between their feelings, what their bodies tell them about themselves, and what they will have to face when their dream becomes blurred and turns into a nostalgic memory of an unreturnable past. An appreciative reading of Love, Again and La carne allows us to see that they reinstate women's place in ageing processes: their words, their bodies, and their action through the recognition of their individuality in the face of the collective, with the physical space that is the body, and that other symbolic space where words are formed, the space from which life emerges. This is a political necessity that traverses all orders of life and affects the construction of the present and future society. The hope is that this paper can contribute to further current understandings of women's ageing processes in fictional narratives, by defining and constructing new viewpoints on the recognition and integration of those involved in this, at times painful, process.

\section{WORKS CITED}

Adón, Pilar (2019), Las órdenes, Madrid, La Bella Varsovia.

Bazin, Victoria (2008), “Commodifying the Past: Doris Lessing's The Golden Notebook as Nostalgic Narrative", The Journal of Commonwealth Literature, 43 (2): 117-131.

Bezhanova, Olga (2020), "Eastern European Immigrants in the Spanish Crisis Novel: Crematorio by Rafael Chirbes and La carne by Rosa Montero", Bulletin of Contemporary Hispanic Studies, 2 (1): 1-16.

Bruner, Jerome (2004), Realidad mental y mundos posibles: los actos de la imaginación que dan sentido a la experiencia, Barcelona, Gedisa.

Carson, Anne (2019), Si no, el invierno. Fragmentos de Safo, Aurora Luque (trad.), Madrid, Vaso Roto.

Castro, Juana (2009), Vulva dorada y lotos, Madrid, Sabina.

-(2010), “Toda la piel del mundo", Heredad, seguido de Cartas de enero, Sevilla, Fundación José Manuel Lara.

Escandell, Dari (2011), “Francés Díez, M. Àngels (2010): Literatura i feminisme. L'hora violeta, de Montserrat Roig”, Revista de Filología Románica, 28: 227-284.

Feigel, Lara (2018), Free Woman. Life, Liberation and Doris Lessing, London, Bloomsbury.

Fox, Nick (2013), “Creativity, Anti-humanism and the 'New Sociology of Art”, Journal of Sociology, 51 (3): 522-536. 
Friedan, Betty (2006), Fountain of Age, New York, Simon \& Schuster. [1993]

García Navarro, Carmen (2003), La vejez como materia literaria en la narrativa reciente de Doris Lessing, Almería, Editorial Universidad de Almería.

-(2019), “'Oh, there are so many things I want to write'. Becoming an Author: Doris Lessing and the Whitehorn Letters from 1944 to 1949", International Journal of English Studies, 19 (2): 19-36. <https://revistas.um.es/ijes/article /view/ 361541/277151>

Gohrbandt, Detlev (1998), "Fable Traditions in the Stories of Doris Lessing and Bessie Head", Across the Lines. Intertextuality and Transcultural Communication in the New Literatures in English, Wolfgang Kloos (ed.), Amsterdam, Rodopi: 129-140.

Greene, Gayle (1994), Doris Lessing: The Poetics of Change, Ann Arbor, Michigan UP.

Gruia, Ioana (2016), "Mujer y familia en las obras literarias de Doris Lessing y Almudena Grandes (los casos de 'La habitación diecinueve' y 'La buena hija')”, Philologica Jassyensia, 24 (2): 209-219.

Güell i Devesa, Mia (2015), La memòria fragmentada a les Reflexions de la vellesa d'Ana Murià, doctoral thesis, Vic, Universitat de Vic-Universitat Central de Catalunya.

Gullette, Margaret (2004), Aged by Culture, Chicago, University of Chicago Press. Hepworth, Mike (2000), Stories of Ageing, Maidenhead, Open UP.

Kaplan, Sydney Janet (1974), "The Limits of Consciousness in the Novels of Doris Lessing”, Doris Lessing: Critical Studies, Annis Pratt and L. S. Dembo (eds.), University of Wisconsin Press: 119-132.

Larrosa, Jorge (1996), La experiencia de la lectura. Estudios sobre literatura y formación, Barcelona, Laertes.

Lessing, Doris, (1994), The Golden Notebook, London, Flamingo.

-(1995), Under My Skin. Volume One of My Autobiography, to 1949, London, Flamingo.

-(1997), Love, Again, London, Flamingo.

Liang, Xiang-Wei and Hui-Quing Yao (2010), "Religious Salvation Versus Redemption of Humanity. A Comparison between Pearl S. Buck's Pavilion of Women and Doris Lessing's The Grass Is Singing", Airiti Library, 25 (3): 37-39.

Mesa, Sara (2018), "Doris Lessing, o el feminismo ambiguo", Letras Libres, 1/4/2018. <https://www.letraslibres.com/espana-mexico/revista/doris-lessingo-el-feminismo-ambiguo $>$

Montero, Rosa, (1981), La función Delta, Barcelona, Círculo de Lectores.

240

Lectora, 27 (2021): 227-242. ISSN: 1136-5781 D.O.I.: 10.1344/Lectora2021.27.11 
-(2013), "Doris Lessing: la escritora combativa", El País Semanal, 18/11/2013. $<$ https://elpais.com/elpais/2013/11/18/eps/1384789527_914633.html>

-(2017), La carne, Barcelona, Penguin-Random House.

Moszczyńska-Dürst, Katarzyna and Rodrigo Pardo Fernández (2013), "Hacia una lectura sociocrítica de La función Delta y Te trataré como a una reina, de Rosa Montero", Sociocriticism, 25 (1/2): 371-393.

Ostriker, Alicia (2014), The Old Woman, the Tulip and the Dog, Pittsburgh, University of Pittsburgh Press. [2009]

Perrakis, Phyllis Steinberg (1999), "The Whirlpool and the Fountain: Inner Growth and Love, Again", Spiritual Exploration in the Works of Doris Lessing, Phyllis Sternberg Perrakis (ed.), Westport \& London, Greenwood: 83-108.

Ramos Toro, Mónica (2017), Envejecer siendo mujer. Dificultades, oportunidades y retos, Barcelona, Edicions Bellaterra.

Redondo Goicoechea, Alicia (2009), Mujeres y narrativa. Otra historia de la literatura, Madrid, Siglo XXI.

Rogers, Richard; Natalia Sánchez-Querubín and Alexander Kil (2020), Issue Mapping for an Ageing Europe, Amsterdam, Amsterdam UP.

Roig, Montserrat (1985), "Mujer y literatura”, Diálogos: artes, letras, ciencias humanas, 21 (5/125): 27-32.

Rubenstein, Roberta (1994), "Fixing the Past: Yearning and Nostalgia in Woolf and Lessing", Woolf and Lessing Breaking the Mold, Ruth Saxton and Jean Tobin (eds.), London, St. Martin's Press: 15-38.

-(2001), Home Matters: Longing and Belonging, Nostalgia and Mourning in Women's Fiction, London, Palgrave-Macmillan.

Russo, Lucia (2017), "El poder curador de la escritura en La carne de Rosa Montero y Mi Sa Che Fuori É Primavera de Concita de Gregorio", Actio Nova: revista de teoría de la literatura y literatura comparada, 1: 69-95.

Sarton, May (2003), “Toward another Dimension”, Images of Aging: Cultural Representations of Later Life, Mike Featherstone and Andrew Wernick (eds.), London, Routledge: 229-231.

Scott, Lynda (1997), "Similarities Between Virginia Woolf and Doris Lessing", Deep South, 3 (2): 42-66.

Segal, Lynne (2014), “Temporal Vertigo: The Paradoxes of Ageing”, Studies in Gender and Sexuality, 15: 214-222.

Sprague, Claire (1994), "Multipersonal and Dialogic Modes in Mrs Dalloway and The Golden Notebook", Woolf and Lessing Breaking the Mold, Ruth Saxton and Jean Tobin (eds.), London, St. Martin's Press: 3-14. 
Thorpe, Rachel; Bianca Fileborn, Gail Hawkes, Marian Pitts and Victor Minichiello (2015), "Older and Desirable: Older Women's Accounts of Ageing Bodies in Intimate Relationships", Sexual and Relationship Therapy, 30 (1): 156-166.

Tiger, Virginia (2007), "Sleepers Wake. The Surfacing of Buried Grief in Doris Lessing's Love, Again, Paule Marshall's Praisesong for the Widow, and Margaret Drabble's The Seven Sisters", Adventures of the Spirit. The Older Woman in the Works of Doris Lessing, Margaret Atwood and Other Contemporary Women Writers, Phyllis Sternberg Perrakis (ed.), Columbus, Ohio State UP: 27-46.

Watkins, Susan (2015), Doris Lessing, Manchester, Manchester UP.

Waxman, Barbara Frey (1990), From the Hearth to the Open Road: A Feminist Study of Aging in Contemporary Literature, Westport, Greenwood.

Wittmann, Reinhard (1997), “¿Hubo una revolución en la lectura a finales del siglo XVIII?", Historia de la lectura en el mundo occidental, Guglielmo Cavallo, Roger Chartier and Robert Bonfil (coords.), Madrid, Taurus: 435-472.

Worth, Nancy, and Irene Hardill (eds.) (2015), Researching the Lifecourse. Critical Reflections from the Social Sciences, Bristol, Policy Press. 